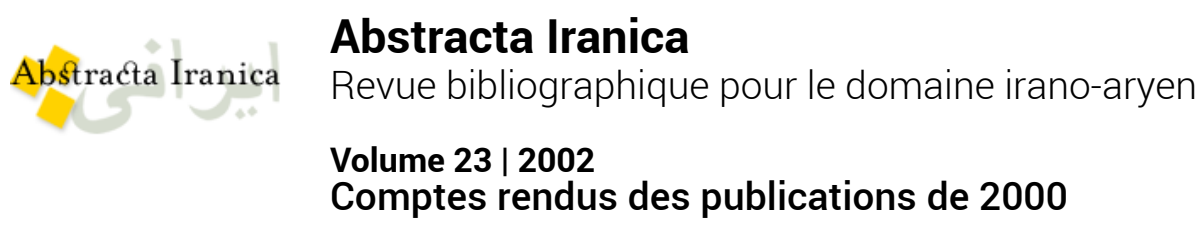

\title{
Noh kelīd. Tehrān, Ṭūs, 1378/1999, 119 p. [Les neuf clés, recueil de contes du Khorassan 3]
}

\section{(2) OpenEdition}

1 Journals

Édition électronique

URL : http://journals.openedition.org/abstractairanica/35955

DOI : 10.4000/abstractairanica.35955

ISSN : 1961-960X

Éditeur :

CNRS (UMR 7528 Mondes iraniens et indiens), Éditions de l'IFRI

Édition imprimée

Date de publication : 15 mai 2002

ISSN : 0240-8910

Référence électronique

« Noh kelìd. Tehrān, Tūs, 1378/1999, 119 p. [Les neuf clés, recueil de contes du Khorassan 3] », Abstracta Iranica [En ligne], Volume 23 | 2002, document 253, mis en ligne le 08 février 2010, consulté le 25 septembre 2020. URL : http://journals.openedition.org/abstractairanica/35955 ; DOI : https:// doi.org/10.4000/abstractairanica.35955

Ce document a été généré automatiquement le 25 septembre 2020

Tous droits réservés 


\section{Noh kelìd. Tehrān, Ṭūs, 1378/1999, 119 p. [Les neuf clés, recueil de contes du Khorassan 3]}

Voir c.r. $n^{\circ} 250$

INDEX

Thèmes : 11.1.0. Généralités 